\title{
MISOGINIA O MIEDO EN LA PICARESCA FEMENINA
}

\section{Introducción}

La picaresca femenina ha estado siempre relegada a un segundo plano por las novelas de protagonista masculino (desde El lazarillo de Tormes hasta el Simplicius Simplicissimus de Grimmelshausen). Las características principales del género han sido establecidas a partir del Guzmán de Alfarache de Mateo Alemán, pese a la precariedad inherente a un enfoque tan limitado. De hecho, muchos de los rasgos considerados como paradigmáticos del género picaresco y del carácter del pícaro no son aplicables - 0 al menos, no lo son de un modo absoluto- a la picaresca femenina.

Las novelas protagonizadas por mujeres presentan peculiaridades impuestas tanto por el sexo de la protagonista como por la distancia entre autor y narrador autobiográfico. Por ser mujeres, las pícaras tendrán que amoldarse a una sociedad rígidamente patriarcal que las somete a restricciones en su afán de movimiento y en sus sueños de realización. A su vez, el desajuste autornarradora va a revertir en una fuerte manipulación ideológica de los textos.

De ahí que quiera reflexionar a lo largo de este artículo sobre un aspecto muy concreto: el tratamiento del ascenso social en la picaresca femenina a través de las siguientes obras: La Pícara Justina del licenciado Francisco López de Ubeda, La Pícara Coraje de H. J. Ch. von Grimmelshausen y Moll Flanders de Daniel Defoe. La primera aparece en 1605 como parodia inmediata de la novela de Mateo Alemán. Justina dice ser una pícara por los cuatro costados, desenvuelta, burlona, mordaz e impenitente, orgullosa de su ascendencia celestinesca y de su matrimonio con Guzmán. En 1670 se publica La picara Coraje, relato que se desarrolla en el entorno cronológico de la Guerra de los Treinta años y que aparece justificado por el afán de venganza de la protagonista, deseosa de pagar con la humillación y la deshonra una burla que le había hecho Simplicius. Moll Flanders pertenece ya al siglo XVIII (1722). Es una novela vinculada a la tradición de la biografia criminal y marcada por el espiritu capitalista y protestante de la época.

Estas tres obras no agotan evidentemente toda la panorámica de la picaresca femenina. Debemos tener presente, además, La hija de la Celestina de Jerónimo de Salas Barbadillo (1612), La niña de los embustes, Teresa de Manzanares (1632) y La garduña de Sevilla y anzuelo de bolsas (1642), ambas de Alonso de Castillo Solórzano. Pese a que en esta ocasión no es mi intención ocuparme de dichas obras, creo que las conclusiones son lo suficientemente generales como para aplicarse sin distorsión a todas las novelas de protagonista femenino.

Quisiera señalar finalmente que he recurrido a un enfoque crítico enormemente suspicaz: desconfio de la pícara, desconfio del autor como creador de personajes verosimiles y desconfío de las intenciones exclusivamente moralizantes que declara tener en los prólogos y aprovechamientos. Esta metodologia de la desconfianza me obliga a tener en cuenta tres aspectos:

- logros conseguidos por las pícaras en oposición a los pícaros,

- posibilidades efectivas de ascenso social en la época,

- tratamiento del tema por parte del autor, es decir, si hay o no desajuste entre realidad y ficción y por qué. 
Intentaré demostrar que el triunfo de las pícaras en su deseo de medro social a través del matrimonio no es más que un recurso literario al servicio de la misoginia de la época y a costa del realismo del relato. Esta distorsión interesada de la realidad a través de la manipulación narrativa caracteriza a las novelas picarescas del siglo XVII, pero no se aprecia con tanta intensidad en Moll Flanders. ${ }^{1}$

\section{2. “Válgame Dios! que aún a mí me toca y yo soy alguien.” Ambición y movilidad social.}

Un rasgo esencial del carácter picaresco es la ambición. La vida del pícaro se inicia con una protesta y con una esperanza casi suicida. Su voz es la del insatisfecho y la del inconformista. No acepta una sociedad que le condena por nacimiento y decisión supuestamente divina a la pobreza irremediable y sumisa. No quiere ser pieza de cartón en un enorme "puzzle" que otras manos componen; se niega a ser sujeto de un código civil que no le contempla como persona con derechos, y no quiere pagar tampoco con la frustración de toda una vida las deficiencias de un sistema social que sólo favorece a la nobleza.

No tiene vocación de rebelde ni de revolucionario. No aspira a transformar la sociedad sino a integrarse en ella: él, caballero, ella, dama. Cuando la eternidad no tiene fuerza bastante para justificar los grilletes, la vida se convierte en apuesta del yo contra los otros, en reto renovado dia a día. Egoista, materialista y egocéntrico, no cree en la solidaridad, desconfía de todos porque aprende con los desengaños y no sabe lo que significa tener un proyecto en común: "Todos caminan a viva quien vence" - comenta Guzmán (pág. 154). Su sueño es personal, intrasferible y solitario: cambiarse de lugar en el tablero de juego: ser reina o caballo, mas no peón.

Con ese convencimiento de piedra que sólo conceden el hambre y los afanes frustrados, el pícaro y la pícara creen que pueden ascender, que el haber nacido les da derecho a esperar y desear. No importa cómo. Su objetivo es conseguirlo. Recordemos el esmero con que Guzmán se viste y acicala para presentarse ante las damas como un caballero (libro II, cap. VIII). La misma presunción se adivina en el pequeño Pablos que quiere aprender virtud en la escuela (Libro 1, cap. I). A Justina le basta una romería para regresar a Mansilla con nuevas ambiciones:

“...Se me puso en la cabeza salir de aldeana y montañesa y dar de súbito en ciudadana porque yo ya era dama; ya las cosas de Montaña y de Mansilla, que todo es uno, me olian a aceite de alacranes." (pág. 132)

Con sólo ocho años, Moll ya tenía bien claro que no habia nacido para sirvienta:

“... pues !ay!, para mi, ser dama era poder trabajar por mi cuenta y ganar lo bastante para mantenerme, sin tener que pensar en el horror de ponerme a servir." (pág. 17)

$\mathrm{Y}$ ante la perspectiva de casarse con un comerciante, no duda en reconocer que no le valía cualquiera.

“... la verdad es que deseaba un comerciante que tuviese también algo de caballero; que cuando mi esposo quisiera llevarme a la corte, o al teatro, no resultara grotesco con la espada al cinto, y pareciese tan caballero como cualquier otro hombre; y que no fuera uno de éstos en cuya ropa se advierte siempre la señal de las cintas del delantal y en cuya peluca se nota la huella del sombrero; que cuando llevara la espada pareciese nacido con ella al cinto, y que en su aspecto nada delatase su oficio.

Bueno, por fin encontré este anfibio, este cruce que se llama caballero-comerciante." (pág. 68) 
No menos orgullosa es Coraje, que se enamora siempre de capitanes, tenientes y caballeros, nunca de soldados rasos. Si en cierta ocasión aceptó por esposo a un mercader fue porque, a pesar de "la vergüenza de tener que pasar de esposa de capitán a cantinera", vislumbraba que el matrimonio seria un buen negocio (pág. 141).

El deseo de ser más, de alcanzar un status elevado que comporte honra y riqueza, prestigio y comodidad es el motor que da sentido a la vida de estos pícaros. Su descontento vertido en actos de protesta -algo que hubiera sido insólito en la Edad Media- nos remite a una sociedad en proceso de cambio. El hecho de que un desharrapado como Guzmán osase reivindicar para sí un puesto distinto al que le había sido otorgado por nacimiento nos demuestra que la antigua estructura estamental, estática y diseñada por Dios, había dejado de ser un ideal de paz unánimemente aceptado.

A ello habian contribuido varios factores: por una parte, el Renacimiento había dejado en los espíritus una secuela de individualismo y autoestima. "Válgame Dios!, que aún a mí me toca y yo soy alguien" -se dice a si mismo Guzmán. El hombre que descubre su valia y su derecho a existir con dignidad no puede conformarse con la panacea medieval del conformismo y la resignación. La sumisión tantas veces predicada desde el púlpito era la negación misma de ese sentimiento de orgullo y autoestima. ${ }^{2}$

Íntimamente vinculada a esta actitud individualista, una burguesía emprendedora y cada vez más prepotente ostentaba por las calles un status comprado con dinero. Para los nuevos burgueses era inadmisible la visión idilica de la pobreza como estado preferido de Dios y al tiempo que ellos ganaban poder económico y prestigio, perdia credibilidad el viejo argumento de la legitimación divina de la pirámide social. Su ejemplo confirmaba dia a dia las sospechas de los desheredados: la suerte no estaba predestinada.

Ambición y dinero: muy atrás ha quedado la sociedad perfecta descrita y defendida por don Juan Manuel en el Libro de los estados. El dinero ha hecho permeables fronteras hasta entonces infranqueables. La naciente sociedad del siglo XVII se caracteriza por el inconformismo, la circulación monetaria y la movilidad social.

Son interesantes en este sentido las siguientes palabras de Antonio Dominguez Ortiz sobre el estamento de la nobleza:

"En el siglo XVI la jerarquía nobiliaria, antes borrosa, se afirmó con el estatuto de la grandeza, la creación en masa de títulos, la burocratización de la concesión de hábitos y la cada vez más marcada diferencia económica entre los caballeros y señores de vasallos, de una parte, y los simples hidalgos, de otra. En el trascurso del siglo XVII las diferencias se acentúan, y a fines del mismo puede advertirse claramente la cesura entre nobles y grandes, que en el futuro serian los únicos que en la consideración del vulgo serian tenidos por nobles, y los caballeros e hidalgos, destinados a fundirse con las clases medias, cuando no a ser proletarios. Aún tardaria en consumarse este fenómeno, pero la trayectoria se apreciaba con toda claridad. De aquí, ante la desvalorización creciente de las categorías nobiliarias inferiores, el afán de conquistar títulos, y como la Corona lo aprovechó para crearse una fuente de ingresos, la contaminación de las categorias nobiliarias por las económicas disoció por completo la teoría de la realidad...". (Dominguez Ortiz (1964), pág. 175)

Como vemos, la jerarquía nobiliaria estaba experimentando una remodelación dirigida por el dinero. Los hidalgos luchaban por convertirse en caballeros; los caballeros, por alcanzar el hábito o conseguir un título, y los títulados por ser grandes. Si en 1520 había en Castilla veinte grandes y treinta y cinco títulos, a fines del reinado de Felipe II se habian convertido en un centenar. 
Pero la movilidad social no sólo era posible dentro del estamento nobiliario. El dinero también circulaba en el estado llano entre burgueses y pecheros acaudalados, que alcanzaban fácilmente la hidalguía sobornando a jueces y regidores para que falsificasen los padrones: ${ }^{3}$

“...el municipio, ganado por las dádivas o el favor, consentía en incluir en la nómina de hidalgos al que no lo era; muchos extranjeros consiguieron ser admitidos por nobles en Sevilla, tomando primero vecindad en algún pueblecito de sus cercanias, donde no les resultaba dificil convencer a sus regidores." (Dominguez Ortiz (1964), pág. 175).

El otro medio, muy común y sencillo, era probar ascendencia montañesa. Bastaba convencer al sacristán para que hiciese un pequeño retoque en los libros de bautismo y casamientos. Como consecuencia, fue tal el aumento del número de nobles que la Corona prohibió la admisión de nuevas demandas. En 1553 Felipe II ordenó expresamente la revisión de las hidalguias recientes "para volver sobre las que se habian alcanzado por malos modos." Pero -tal y como señala Dominguez Ortiz-, "ni leyes ni castigos pudieron impedir unos abusos que nacian del espíritu de la época (...) en todas partes, el plebeyo enriquecido hallaba facilidades para introducirse en la hidalguía, y el hidalgo empobrecido dificultades para conservarla" (págs. 176 y 178). De hecho, pese a las órdenes en contra, la misma Corona favoreció el ascenso de muchos plebeyos, pues muy a menudo recurría a la venta de hidalguias (cuyo precio descendió en el siglo XVII de 4000 a 1000 o 2000 ducados e incluso menos) para costearse las guerras. No debieron de ser pocos los que buscaron el ascenso a través de la milicia:

"Las interminables guerras del siglo XVI ofrecieron abundante ocasión a los que buscaban ennoblecerse con sus proezas; a veces se ofreció la hidalguia a los que militaban a caballo a su costa, e incluso a fines de siglo, cuando la vocación guerrera estaba casi perdida, muchos acudieron en 1683 a la guerra contra los turcos, combatieron delante de Viena, tomaron parte en el asalto de Buda y volvieron provistos de certificados de sus hazañas, que utilizaron para sus pretensiones de nobleza." (Domínguez Ortiz (1964), págs. 184-185)

De esto nos da testimonio Adelhold, uno de los personajes que aparecen en Simplicius Simplicissimus:

"Cuando se observan las virtudes de probidad de un hombre honrado no pasará lógicamente inadvertido. Tanto más cuanto hoy en dia se encuentra gente que habiendo cambiado el arado, la aguja, la lezna y el pastoreo por la espada, han alcanzado, gracias a su comportamiento y valentía, llegar más allá de la nobleza ordinaria, hasta el título de conde o barón." (Cap. XVII, pág. 93)

$\mathrm{Su}$ interlocutor reconoce que todos se alistan con la esperanza del ascenso pues " $i$ Quién será $\tan$ loco que quiera servir en el ejército si no tiene esperanzas de ascender por su buena conducta y ver recompensados sus fieles servicios?" Simplicius, por su parte, habla del "continuo bullir y trepar en este árbol (el de la milicia), porque todos querian estar en los dichosos lugares superiores."

Sin embargo, el ascenso no era empresa fácil para los plebeyos debido a los privilegios con que contaba la nobleza:

“...yo puedo ver también -comenta un sargento- que la nobleza nos cierra las puertas para tal o cual dignidad nada más salir del caserón, la nobleza llega a algunos lugares con los que nosotros no podemos ni soñar, aunque hayamos hecho más méritos que muchos nobles que ahora son coroneles. Y lo mismo que entre aldeanos se malogran algunos ingenios nobles por falta de medios para acceder a los estudios, igual hay soldado que envejece con su mosquete al hombro, que podría muy bien mandar un regimiento y prestar valiosos servicios al general en jefe." (Cáp. XVII, pág. 94) 
De hecho, en el árbol de la milicia soñado por Simplicius, la parte del tronco que separa a los de arriba de los de abajo (obreros, jornaleros, labriegos...) era "un espacio liso, sin ramas, embadurnado con unas sustancias maravillosas y con el extraño jabón de la mala suerte, de tal modo que nadie, al menos que no fuese de la nobleza, podía trepar por él ni por valentía, destreza o conocimientos, pues estaba más liso y pulido que una columna de mármol o un espejo de acero." Asi se explica la utilidad de esas "escaleras de plata llamadas corrupción" que menciona el pícaro (Cap. XVI, págs. 89-90).

También Guzmán -recordémoslo- decidió en cierta ocasión alistarse en el ejército "que sólo eso buscaba para salir de congojas”. El capitán, creyéndole noble, le estimuló con la perspectiva de un futuro halagüeño:

"En Italia es otro mundo y le doi mi palabra de le hacer dar una bandera. Que, aunque es menos de lo que merece, será principio para poder ser acrecentado." (Parte I, libro $2^{\circ}$, cap. IX, págs. $339-340)^{4}$

Por supuesto, nada salió como Guzmanillo esperaba.

En cualquier caso, milicia, soborno y compra de hidalguías eran tres puertas abiertas al ascenso social. Lícita o ilícitamente, por méritos personales $o$, más frecuentemente, sobornando a regidores corruptos, aprovechando la ausencia de padrones en una aldea o convenciendo a un sacristán, los plebeyos adinerados se convertían en hidalgos y osaban menospreciar a los hidalgos de linaje. Éstos, empobrecidos por negarse a trabajar en oficios viles, se hundian en una lastimosa situación de desmoralización y desprestigio (buen ejemplo es el caballero de Lázaro). Además, desde el momento en que la hidalguía se hizo algo corriente, perdió también su antigua valoración social. Pensemos que incluso la regenta de una posada como la que aparece en El coloquio de los perros cervantino podía ostentar, orgullosa, su carta de ejecutoria:

"Mandó el alguacil que se cubriese y se viniese con él a la cárcel, porque consentía en su casa hombres y mujeres de mal vivir. ¡Aquí fue ello! ¡Aqui sí que fue cuando se aumentaron las voces y creció la confusión!; porque dijo la huéspeda: "Señor alguacil y señor escribano no conmigo tretas, que entrevo toda costura; no conmigo dijes ni poleos; callen la boca y váyanse con Dios (...) porque yo soy mujer honrada y tengo un marido con su carta de ejecutoria, y con a perpenan rei de memoria, con sus colgaderos de plomo, Dios sea loado, y hago este oficio muy limpiamente y sin daño de barras. El arancel tengo clavado donde todo el mundo le vea; y no conmigo cuentos, que, por Dios, que sé despolvorearme." (Cervantes (1989), págs 325-326)

Sin embargo, pese a la enorme movilidad registrada desde fines del siglo XVI (muchos plebeyos convertidos en hidalgos; muchos hidalgos tratados como plebeyos), sería ingenuo pensar que todos pudieron sacar partido de esta situación. Fueron también muchos los que ahogaron sus aspiraciones por falta de medios económicos para costearse la hidalguía. Entre ellos se encontraban los pícaros, la sección más inconformista de los pecheros pobres. La novela picaresca -como ha señalado José Antonio Maravall- es la novela de la frustración del medro:

"En las condiciones sociales y económicas de los siglos XVI y XVII, ¿les era posible que por algún conducto regular llegaran a acumular riquezas, hasta permitirles mudar de estado, a desdichados jovenzuelos, pobres por su origen familiar, de padres que por una u otra razón vivian en la infamia, que pesaba sobre ellos la tacha legal del ejercicio de trabajo mecánico, etc.? ¿basta, como afirmaba Luis Mexía, con ponerse a trabajar hasta sudar "para adquirir riqueza para sustentar honra", aunque ésta fuera en los niveles más infimos? Indudablemente, no." 
El servicio ya no era como antaño. La relación amistosa y paternal que vinculaba al señor con su criado había sido sustituida por un frio contacto, afrentoso y desigual: el trabajo era abundante y los sueldos, escasos. Tras servir durante un año como paje de un cardenal, Guzmán hace la siguiente reflexión:

"Preguntado al cabo dello "¿qué tenéis horro, que se ha ganado?", la respuesta está en la mano: "Señor, sirvo a mercedes, he comido y bebido, en invierno frio, en verano, caliente, poco, malo y tarde. Traigo este vestido que me dieron y no tanto con que me cubriese, cuanto con que sirviese; no para que me abrigase, sino con que los honrase. Hiciéronlo a su gusto y a mi costa; diéronme por mis dineros las colores de su antojo. Lo que habremos medrado en abundancia ha sido resfriados, que no hay hombre que pueda alzar un plato; granos y comezón con que nos entretenemos, y otras cosas de frutillas tales o peores. Cuando el viento corre fresco y alcanzamos valor de diez o doce cuartos todo en grueso, ha sido de otros tantos pellizcos o bocados de cera que quitamos a la hacha y los vendemos a un zapatero de viejo. El que puede acaudalar un cabo, ya ese tiene patrimonio, hace grandezas, compra pasteles y otras chucherias; mas acaso si en ello lo hallan, en azotes lo paga, que es su juicio." (págs. 410-411)

Guzmán también intentará probar suerte en la milicia, pero ya vimos las escasas posibilidades de medro que se le ofrecían al soldado de origen plebeyo. Lo más probable es que regresase roto, cansado, miserable, viejo, enfermo y desilusionado o que, en el peor de los casos, ni siquiera regresase. Las honras - comentaba el sargento de Simplicius- estaban reservadas a la nobleza:

“... murmuramos de la corta mano de los hombres valerosos y cuán abatida estaba la milicia, qué poco se remuneraban servicios, qué poca verdad informaban dellos algunos ministros, por sus propios intereses..." (pág. 338)

Asi las cosas, al picaro sólo le queda una salida: el trabajo, pero es ingrato, mina el orgullo y ata con cadenas a la pobreza. Por eso, sólo se rebajará a trabajar en casos de extrema necesidad. Rinconete, Cortadillo y Guzmán fueron durante algún tiempo esportilleros y éste último trabajó también como mozo de ventero. Sin embargo, las apariencias le preocupan más que el hambre. Tiene muy claro que antes de trabajar, prefiere mendigar.

"Siendo aquella para mi una vida descansada, nunca me pareció bien, y menos para mis intentos. Porque, al fin, era mozo de ventero, que es peor que de ciego. Estaba en camino pasajero: no quisiera ser alli hallado y en aquel oficio, por mil vidas que perdiera. Pasaban mozuelos caminantes de mi edad y talle, más y menos, unos con dinerillos, otros pidiendo limosna. Dije: "Pues, pese a tal, ¿he de ser más cobarde o para menos que todos? Pues no me pienso perder en pusilánime.” (pág. 257)

Su reacción era lógica. Por pícaro que sea, ha nacido con alma de caballero y aspira a un status que le permita llevar una vida ociosa y acomodada. Trabajar en una venta es una ofensa a su dignidad. Pero la distancia entre propósitos y posibilidades es demasiado profunda; la frustración, inevitable, y ésta genera un odio tan intenso como las ilusiones deshechas. Los pícaros están atrapados en la miseria, en la marginalidad. Su libertad era también un sueño. Se engañaron... Recordemos al Guzmán que se encaminaba a la corte madrileña cargado de esperanzas y proyectos (parte primera, libro II, cap. I y II):

"Parecióme que por mi persona y talle todos me favorecerían y allá llegado anduvieran a puñadas haciendo diligencia sobre quién me llevara consigo."

La realidad fue muy distinta; el desengaño, inmediato:

“Cuánto distan las obras de los pensamientos! ¡Qué hecho, qué frito, qué guisado, qué fácil es todo al que piensa; qué dificultoso al que obra! ... iQué bien se disponen las cosas de noche 
a escuras con el almohada! Cómo saliendo el sol al punto las deshace como a la flaca niebla en el estío! ... Fueron castillos en arena, fantásticas quimeras. Apenas me vestí, que todo estaba en tierra. Tenia trazadas muchas cosas: ninguna salió cierta, antes al revés y de todo punto contraria. Todo fue vano, todo mentira, todo ilusión, todo falso y engaño de la imaginación, todo cisco y carbón, como tesoro de duende." (págs. 250-251)

Tras la frustración, la rabia, y tras la rabia, la delincuencia:

"Viéndome tan despedazado, aunque procuré buscar a quien servir, acreditándome con buenas palabras, ninguno se aseguraba de mis obras malas ni quería meterme dentro de casa en su servicio, porque estaba muy asqueroso y desmantelado. Creyeron ser algún pícaro ladroncillo que los habia de robar y acogerme.

Viéndome perdido, comencé a tratar el oficio de la florida picardía. La vergüenza que tuve de volverme, perdila por los caminos..." (pág. 258)

Como hemos visto, la inestabilidad social ofrecía numerosas posibilidades de medro, pero todas estaban vedadas a los pícaros. ¿Estaban sus compañeras en la misma situación? ¿podemos establecer diferencias entre la picaresca masculina y la femenina? ¿cómo se desenvuelven las pícaras en la sociedad patriarcal y endocéntrica del siglo XVII? ¿Son relatados sus afanes con el mismo realismo? y, en última instancia, ¿qué probabilidades tenia una mujer real de que sus ambiciones se cumpliesen y en qué medida se reflejan éstas en los textos? Las preguntas, como vemos, se acumulan: vale la pena ir en busca de respuestas.

\section{La ambición de la pícara}

En primer lugar, hombres y mujeres coincidian en sus sueños (prestigio, riqueza), pero no contaban con los mismos medios. Él era libre, podía aspirar a honras militares, a enriquecerse en el comercio si tenía vocación burguesa a a adquirir una hidalguía si contaba con el capital suficiente. La mujer, sin embargo, no era dueña de sí misma, pasaba del poder del padre o del hermano al del marido y no le quedaba más salida que la de rezar para que el primero no errase demasiado en la elección de su futuro esposo. ${ }^{6} \mathrm{Si}$ era de origen noble, su ideal sería un caballero con hábito, un Título o, por qué no, un Grande de España. Si pertenecía a una familia burguesa acomodada, podria aspirar a un hidalgo acaudalado o a un caballero de prestigio. En cualquier caso, si era hermosa (aunque no demasiado), casta, sumisa, obediente, virtuosa y, sobre todo, si podía ofrecer una dote cuantiosa, al padre no le resultaría dificil encontrar un buen partido entre los numerosos pretendientes que la solicitarían. La recién casada podía y debía estar contenta y satisfecha porque habia aumentado la honra familiar y se habia casado por encima de su clase. El amor era lo de menos en una sociedad que consideraba el matrimonio un mero contrato económico. De hecho, un moralista tan sobresaliente como Juan Luis Vives piensa que no se deben hacer matrimonios "por vias de amores, ni con tan frágiles nudos atar tan gran carga." La incidencia del dinero en la deshumanización de las relaciones interpersonales se hará, si cabe, más dramática con el establecimiento de la ideología capitalista y del mercado. El testimonio de Moll es conmovedor:

"La experiencia no tardó en enseñarme una cosa: (...) que los matrimonios aquí eran el resultado de una serie de hábiles cálculos para hacerse con un capital o para ampliar un negocio, y que el amor, o bien no contaba o contaba muy poco.

Que, como habia dicho mi cuñada de Colchester, la belleza, el ingenio, los buenos modales, la discreción, el buen carácter, la buena crianza, la virtud, la piedad, o cualquier otra de estas cualidades, ya fueran fisicas, ya morales, no daban más valor a una mujer; que sólo el dinero hacia atractivas a las mujeres; que ciertamente, los hombres elegian sus amantes dejándose lle- 
var por su inclinación, y que una ramera debia ser hermosa, tener buena figura, un porte agradable y un trato cortés; pero que tratándose de una esposa, ninguna deformidad resultaría repelente, ningún vicio haría cambiar de opinión; el dinero era lo importante; la dote nunca era encorvada ni mostruosamente fea, sino que el dinero era agradable siempre, fuese como fuese la esposa." (pág. 76) 7

Pese a todo, el matrimonio podía ser para la mujer una vía de ascenso social y de enriquecimiento (era, de hecho, la única que tenía en una sociedad fuertemente patriarcal y antifeminista). Para una familia noble, pero empobrecida, no sería nada desdeñable que la hija se casara con un burgués acaudalado; y viceversa, una familia burguesa acomodada no vería con malos ojos a un pretendiente noble, aunque fuese pobre, porque el casamiento aumentaba el prestigio familiar (hubiera sido el caso de Calisto y Melibea si no hubiesen muerto prematuramente).

Ahora bien, casarse no era siempre tan sencillo. Si se retrasaba el matrimonio, las consecuencias eran desatrosas para la mujer. Una doncella de veinticuatro años y sin perspectivas cercanas de boda debía pensar seriamente en la opción de la vida conventual. Por otro lado, nada habia más frágil y vulnerable que una mujer viuda: sin la protección del marido, incapaz de ganarse la vida por sí misma y sometida a la mirada escudriñadora de una sociedad preparada para criticar y censurar la más mínima señal de deshonestidad (la mujer es como una pared blanca sobre la que cualquiera se cree con derecho a escribir -diría sor Juana):

“Si una viuda sale de casa, la juzgan por deshonesta; si no quiere salir de casa, piérdesele su hacienda; si se rie un poco, nótanla de liviana; si nunca se rie, dicen que es hipócrita; si va a la Iglesia, nótanla de andariega; si no va a la iglesia, dicen que es a su marido ingrata; anda mal vestida, nótanla de extremada; si tiene la ropa limpia, dicen que se cansa ya de ser viuda; si es esquiva, nótanla de presuntuosa; si es conversable, luego es la sospecha en la casa; finalmente digo, que las desdichadas viudas hallan a mil que juzquen sus vidas, y no hallan uno que remedie sus penas." 8

Sin embargo, si nos introducimos en el mundo picaresco, observamos que las pícaras tienen una ventaja sobre las demás mujeres de la época: pueden elegir al hombre al que desean someterse e, incluso, pueden llegar a desempeñar el rol masculino en la relación de pareja. Carecen de padres y de hermanos que las obliguen o, si los tienen, como Justina, saben burlar su autoridad. De hecho, frente al reincidente fracaso de los pícaros, sus compañeras de aventuras consiguen a menudo matrimonios ventajosos que les permiten ascender de forma inmediata en la escala social.

Manejan con habilidad a los varones porque conocen el tipo de mujer que les gusta y saben representarlo a la perfección: casta, callada, honrada, obediente y con dinero. Son bellas, arteras, astutas, expertas fingidoras, crueles con los pretendientes incómodos, es decir, pobres; dulces y seductoras con los enamorados de prestigio. Gracias a su hermosura, su astucia y sus artes innatas para el engaño y la seducción consiguen lo que nunca lograron los picaros: el ascenso social y con él, el prestigio y la holgura económica.

Pese a su dudosa reputación, Coraje cuenta entre sus esposos a cuatro capitanes y un teniente. Este último fue elegido por su rango y apostura entre numerosos rivales:

"Tras esta batalla obtuve más enamorados que antes, y puesto que con mi marido había tenido mejores días que noches, máxime cuando desde su muerte guardaba ayuno en contra de mi voluntad, he aquí que decidi reparar tanta abstiencia eligiendo yo misma, así que me prometí a un teniente que, según mi parecer, superaba a los otros rivales en apostura, juventud, inteligencia y audacia. Era italiano por nacimiento, de los de negra cabellera pero de piel clara, y a mis 
ojos tan hermoso que ningún pintor lo habría podido pintar más bello. Me profesaba una sumisión casi como un perrillo - hasta que no me hubo lamido- y cuando obtuvo de mi por fin el sí, manifestó tamaño regocijo como si Dios le hubiese regalado el mundo entero. En palacio nos desposamos y tuvimos el honor de que asistieran el coronel y los más altos oficiales, que nos desearon -por cierto en vano- mucha felicidad y un matrimonio duradero." (pág. 103)

Ningún hombre es capaz de descubrir sus artimañas embaucadoras:

“Me visitaba por aquél entonces un caballero que me agradaba sobremanera, decidido y acaudalado. Hacia él lancé mis redes y no descuidé ninguno de mis engaños hasta que no lo tuve en mi lazo y enamorado a mis pies hasta el punto de que le podía hacer comer de mi mano sin reparo por su parte.

Me prometió, por que le llevasen los diablos, que se casaria conmigo..." (pág. 135)

Y lo mismo le sucedió al capitán de Bragoditz:

"Yo, por mi parte, sabía dármelas de casta, con tan buen oficio, que él apuraba haciéndome ver su desesperación." (pág. 119)

La pícara Justina confiesa haber tenido numerosos pretendientes, pero todos eran como el hijo de la lavandera o el tornero Maximiliano, "amantes campanudos que hacen apariencias y no ofrecen"; de ahi que tras rechazar a muchos de estos enamorados importunos e insignificantes, Justina se desposase con un hombre de armas, pobre pero hidalgo:

"Tres cosas he dicho que rinden a una mujer: interés, presunción e importunidad. Interés, no dudes que le hubo, pues sin quien me amparara, ni mi sentencia era sentencia ni mi hacienda fuera mía. Mi presunción no era poca, pues casando con hijo de algo, había de salir de la nada en que me crié." (págs. 306-307)

Finalmente, también Moll consigue casarse ventajosamente en varias ocasiones. Recordemos al hermano menor de los Colchester, de quien, sin embargo, no estaba enamorada, o al banquero londinense, "hombre apacible, comprensivo, de buen natural; virtuoso, modesto, sincero y honrado y laborioso en sus negocios." (pág. 210). Una sortija de diamantes y cinco años de sosiego, despreocupación económica y consideración social fueron la prueba de su amor por ella.

Como vemos, el devenir aventurero del pícaro está siempre marcado por el hambre, la miseria y la desilusión. La pícara, por el contrario, burla las fronteras de la marginalidad y asciende en la pirámide social mediante una estrategia matrimonial sabiamente trazada. El pícaro nunca deja de ser pícaro. La pícara se convierte en señora. Si es así, la deducción que se desprende de la novela picaresca es obvia: el matrimonio, en manos de una mujer inteligente, es un arma peligrosa capaz de corroer los muros de la estratificación social y superar, así, desniveles de clase insalvables para el varón. La pícara resulta ser un factor de inestabilidad social mucho más potente que su compañero, puesto que sus sueños ilegítimos de ambición pueden llegar a hacerse efectivos.

Ahora bien, si nos conformamos con esta primera lectura, es muy probable que nos estemos dejando engañar. Debemos ser menos crédulos y más supicaces, leer en los huecos que dejan las palabras y preguntarnos si, efectivamente, el mundo literario de la picaresca femenina tenía su paralelo en el mundo real. ¿En la sociedad patriarcal del siglo XVII, los deseos de medro de la pícara se unían a posibilidades reales para cambiar de estado? ¿Estaba el pícaro en desventaja respecto a la picara?

Creo que no; que entre novela y realidad se ha producido un desajuste o desplazamiento, y que este desplazamiento ha sido deliberadamente provocado por los autores. Ningún hombre se hubiera casado con una doncella desconocida sin estar absolutamente seguro de que cumplía los 
requisitos exigidos a una buena esposa en cuanto a carácter, educación, antecedentes familiares y cuantia de la dote. Todavia en el siglo XVIII, Moll Flanders se quejaba de que los hombres podian pedir todo tipo de antecedentes en torno a la mujer escogida, mientras que ésta debia hacer un acto de fe sobre la honestidad de su futuro esposo:

“...me di cuenta -comenta Moll con enojo- de que los hombres no tenían ningún escrúpulo en mostrarse tal cual eran, y en convertirse en cazadores de dotes, que asi los llaman, cuando en realidad ni tenian fortuna semejante a la que pretendian conseguir, ni eran acreedores a ella por sus méritos; y que la cosa llegó a tales extremos que a una mujer ya casi no le estaba permitido hacer averiguaciones acerca del carácter o de la posición de la persona que aspiraba a su mano. De esto tuve un buen ejemplo en una joven de una casa vecina a la mía... Yo le di la razón y califiqué de ruin la conducta de él; le dije que yo, aun siendo tan pobre como era, hubiese despreciado a un hombre capaz de pensar que debia aceptarle sin más recomendación que la suya propia, sin que tuviese la libertad de informarme por mí misma acerca de su fortuna y de su carácter..." (pág. 77)

Es cierto que para la mujer del Barroco, el único medio de liberarse de la tutela del padre y de adquirir un status más elevado pasaba por el matrimonio y de que éste era, por tanto, el sueño de todas las féminas. De hecho, los libros de doctrina de la época sólo reconocen dos estados posibles para la mujer: el matrimonio y el convento. Esto significa que las mujeres podían ser doncellas, casadas, viudas y monjas.

Sin embargo, esta enumeración no es completa porque únicamente hace referencia a las mujeres integradas socialmente: hijas de campesinos, burgueses y nobles a quienes iban dirigidos los consejos y reconvenciones de Vives, Erasmo, Mexía, Fray Luis, Guevara y demás moralistas reconocidos. Aunque hablasen en las iglesias con mancebos opuestos y se asomasen a las ventanas para observar a los transeúntes, aunque participasen con sus comentarios en las tertulias, usasen corpiños escotados y se maquillasen el rostro, estas doncellas rebeldes y despreocupadas se casarian, tendrian hijos, se ocuparian mejor o peor de las labores domésticas y aceptarian, en definitiva, la autoridad de sus maridos. Las que sentían vocación religiosa, las viudas jóvenes y las eternas solteras veinteañeras acabarían recibiendo los hábitos monjiles. Entre los muros del convento, la rebeldía, si la hubo, se asfixiaba pronto o -en el peor de los casos- quedaba oculta.

Ahora bien, además del matrimonio y el convento - las dos únicas salidas "profesionales" de las mujeres virtuosas- había un tercer estado que aglutinaba a doncellas y dueñas no tan honestas ni de tan claro origen: la prostitución. A él pertenecían alcahuetas como la vieja Celestina y rameras como Areusa y Elicia, como La Pericona, La Repulida, La Pizpireta y La Mostrenca, mozas del vivir alegre retratadas por Rojas (La Celestina) y Cervantes (El rufián viudo llamado Trámpagos). ¿Tenemos alguna razón para excluir de esta lista a Justina y Coraje? Creo que no.

Aunque Justina no lo reconozca nunca, son numerosas las alusiones más o menos encubiertas a su verdadera condición. Ella misma gusta de llamarse "hija de Celestina", admira con pasión a su madre, ramera experimentada, cuando escribe sus memorias está completamente calva a consecuencia de unas bubas producidas por el "mal francés" y al principio se define a sí misma con "seis nombres de p": picara, pobre, poca vergüenza, plana y pelada." El último lo pone el lector. Finalmente, refranes como "ir rromera i volver rramera" o "la liebre búscala en el cantón i la puta en el mesón" nos confirman que, para los españoles del siglo de Oro, mesonera y prostituta, romera y ramera eran parejas sinónimas. ${ }^{9}$ 
Coraje, por su parte, no tiene ningún escrúpulo en confesar al lector de dónde provienen sus ahorros:

"Comenzaba por momentos a sentir la presencia del hambre, lo que me convenció sin dificultad para que me pusiera al punto de ganarme el pienso diario con el nocturno bregar." (pág. 134)

Y en otro momento comenta con descaro:

“...decidi confesarle a mi marido todas las andanzas de mi vida... salvo los episodios de ramera que había vivido aqui y allá..." (pág. 120)

Pues bien, es absolutamente inverosimil que una ramera del siglo XVII considerase la posibilidad de casarse. Mucho más inverosímil es que aspire a un matrimonio ventajoso y que lo logre. Si sólo por el hecho de demorarse en el camino de ida y vuelta a la iglesia, una mujer honrada era tachada de callejera y libertina con el consiguiente desprestigio que esto significaba para su honor y el de su familia, mujeres como Justina y Coraje, andariegas, independientes, posesivas, charlatanas, sensuales y decididas, serian inmediata y definitivamente condenadas. Ningún varón, ni siquiera el más plebeyo entre los plebeyos, las miraría como posibles esposas: "no kompres asno de rrekuero, ni te kases con hija de mesonero" - sentencia el refrán.

Si volvemos ahora sobre los textos, comprobaremos que éstos no soportan una lectura detenida y critica.

\section{La inverosimilitud del relato picaresco femenino.}

Coraje se casa nada menos que siete veces, pese a que nunca le abandona su fama de conquistadora de hombres. Vaya donde vaya, su apodo la persigue, prueba de que sus conquistas militares y sexuales estaban muy difundidas entre los soldados:

“...no llevaba apenas un mes en aquel ejército cuando fui a toparme con algunos oficiales que no sólo me habían conocido en Viena, sino que además habían tenido conmigo buenas confidencias. Sin embargo, fueron muy discretos por no hacer escándalo ni de mi honra ni de la suya. Circulaba por ahi, debo decirlo, un pequeño rumor, que no me produjo, sin embargo, el menor atisbo de preocupación, salvo el de tener que seguir soportando el nombre de Coraje." (pág. 100)

\section{Y más adelante:}

“...tal como me ocurriese en Viena, tampoco pude aquí deshacerme del nombre de Coraje, aunque era, de entre mis cosas, la que hubiera cedido por el más módico precio.” (pág. 115)

Cuando piensa en la posibilidad de cambiar de sexo, se resigna al reconocer que "demasiados testigos hubieran desmentido mi farsa" (pág. 113), y en otra ocasión confiesa que "unos y otros decian de mi que era el mismo diablo en persona", caracterización, sin duda, muy poco adecuada para una esposa. De hecho, muchos hombres llegaron a esquivarla e incluso a huirla: "Quédatela tú, que para mi no la quiero" -comentaban, temerosos de caer en sus redes. Ella misma reconoce a veces la ineficacia de sus artes porque "mi fama era conocida por doquier":

“...entre los oficiales... ninguno habia que quisiera casarse conmigo, ya fuera porque se avergonzaban de mi en el augurio de desgracias, habiendo causado tanto perjuicio a mis maridos anteriores. Los había incluso, desconozco por qué razón, que me tenían miedo." (pág. 113)

Pues bien, a la hora de la verdad, nada de esto parece tener relevancia. Tras enviudar de su primer capitán, Coraje no tarda en encontrar un sustituto: 
"Como el caballero, esclavo mío e inundado de amor, no podia soportar la demora de nuestro casamiento, nos desposamos sin más, antes de que pudiese llegar a saber cómo había conseguido la Coraje todo aquel dinero, que no era pequeña cantidad." (pág. 100)

Tampoco el tercer capitán escuchó ningún comentario sobre la dudosa reputación de su prometida ni se preguntó de dónde procedían los mil talegos que Coraje, mujer viuda y huérfana, aportaba al matrimonio. Era tanta la ingenuidad y bondad del noble capitán que cuanto más fama adquiria Coraje como prostituta, más angelical y pura la juzgaba (cap. X). Finalmente, ¿qué caballero en su sano juicio aceptaría casarse con una mujer violada por todo un regimiento? ¿Son acaso los oficiales con que topa la protagonista los únicos hombres del siglo XVII que toleran el adulterio femenino?

Desde luego, los apasionados sentimientos amorosos de los varones no nos merecen ninguna credibilidad en una sociedad materialista y cruda como la de Coraje. Las rídículas declaraciones de amor cortés más bien parecen guiños jocosos del autor divertido a un lector cómplice. Efectivamente, creo que el amor en la picaresca femenina barroca es un mero recurso literario introducido con dos funciones: por un lado, divertir y entretener; por otro, sustentar una verosimilitud endeble y justificar -al menos, aparentemente- esta larga retahila de matrimonios descabellados.

La inverosimilitud llega a tal extremo que el propio Grimmelshausen (a través de la picara) se atreve a ironizar en cierta ocasión sobre la sorprendente suerte de su personaje:

“...mi experiencia y buen hacer me permitieron atrapar una vez más a un capitán, esta vez del ejército de Gallas, el cual se casó conmigo como si fuera de Praga la obligación, o quizá cualidad suya, el procurarme maridos, y en concreto, capitanes." (págs. 181-182)

Esta coletilla final de Coraje más bien parece el comentario inevitable y risueño de un autor consciente de su exageración, pero satisfecho del resultado: de la imagen desvergonzada y desenvuelta de su antiheroina. De hecho, es tan llamativa la inverosimilitud que provoca fácilmente la hilaridad. Por pazgüato que fuese el mosquetero, por enamorado que estuviese (bien sabemos lo poco que importaba el amor en los contratos matrimoniales), es inconcebible que aceptase las seis cláusulas de obediencia y sumisión que le impuso la ambiciosa y altiva Coraje:

"Tan lejos llegué con mi galán, que acordé con él las condiciones siguientes y le hice prometer cumplirlas.

En primer lugar, debía abandonar su regimiento, porque de otro modo no podia servirme y yo no estaba dispuesta a ser mosquetera.

En segundo lugar, debía vivir conmigo y demostrar siempre, como hacen los esposos de verdad, amor y fidelidad a su esposa, lo cual es su obligación, y yo, por mi parte, haria lo mismo con él.

En tercer lugar, este matrimonio no sería, sin embargo, confirmado ante la Iglesia, no siendo que quedase preñada. ${ }^{9}$

En cuarto lugar, tendría yo hasta entonces la potestad no sólo sobre las cosas, sino también sobre mi propio cuerpo y sobre los criados y, del mismo modo que el hombre ostenta poder sobre la mujer, asi haría yo con él.

En quinto lugar, y por todo lo dicho, no le sería posible prohibirme ni privarme de nada, ni mucho menos mirarme con malos ojos cuando conversase con otros hombres, o me permitiese hacer lo que de constumbre llena de celos al marido.

$\mathrm{Y}$ en sexto lugar, puesto que era mi intención dedicarme al comercio, debería ser él quien apareciese como cabeza del negocio y mostrarse activo al frente de éste como celoso y eficiente comerciante, tanto de día como de noche, mas otorgándome pleno poder sobre el dinero y 
soportando con obediencia cambios y rectificaciones cuando quisiese reprenderle por algún descuido.

En resumidas cuentas, debía ser considerado y tratado por todos como el dueño y ostentar tal titulo y distinción, pero guardándome siempre la mencionada obediencia." (págs. 144-145)

Ninguna mujer se atrevería a tanto en el siglo XVII y ningún hombre admitiria una tiranía semejante. Es evidente, por tanto, que estos matrimonios no se hubieran celebrado en el mundo real. ¿Qué consideración social podía merecer una viuda que se dedicaba al pillaje y a "otros menesteres" muy poco honestos? Su carácter era arisco, ladino, descarado y dominante; su forma de hablar, grosera y despreciativa:

“...el verdugo era mi padre y su viejo penco (su venerable señora, quiero decir) era como mi madre."

"...hice volver en sí a mi pelanas (a mi esposo, quiero decir)..."

"Puesto que de esta manera volvía a tener dos asnos, decidí cuidarlos con el mayor esmero, para que cada uno pudiera cumplir su tarea lo mejor posible." (págs. 158, 106 y 193 respectivamente)

No se queda atrás Justina. Es lasciva, libertina, maliciosa, atrevida y deslenguada. Su expresión es desgarrada, hiriente y ofensiva. Así responde al estudiante burlado:

“Por los dientes me cuenta el alma? Bien parece que le mordi. Por lo menos sabe que soy viva, porque muerdo. Con salud lo cuente, y sea tanta que le reviente por los ijares." (pág. 177)

En la primera romeria aparece con un vestido escotado y llamativo que revela su condición de buscona y causa el efecto deseado entre la concurrencia masculina:

"Llevaba un rosario de coral muy gordo... Mis cuerpos bajos, que servian de balcón a una camisa de pechos... Una saya colorada, con que parecía cualque pimiento de Indias... un brial de color turqui, sobre el cual caian a plomo borlas, cuentas y sartas... Mas si los hombres mordieran con los ojos, según fingieron los argótides, ¿qué de tiras llevara mi saya?" (pág. 94)

A partir de este momento, Justina se va a esforzar por hacerse conocida entre los hombres por sus burlas y engaños. Su venganza al estudiante burlado se hace famosa en todo León y la broma cruel que tuvo que padecer el bachiller melado debió de extenderse por toda Mansilla. Con una reputación tan consolidada, es imposible que tuviese la oportunidad de rechazar a tantos pretendientes enamorados. 11

Tras la relectura de ambos relatos, no cabe la menor duda de que la novela picaresca femenina del siglo XVII nos sumerge en una ficción muy lejana de la realidad. Frente al realismo de la novela picaresca masculina, que nos presenta a un pícaro atrapado irremisiblemente en la marginalidad, incapaz de aprovechar las abundantes posibilidades de ascenso social que ofrecía la época, la picaresca femenina nos entrega la vida de unas pícaras triunfadoras que convierten el matrimonio en una estrategia exitosa de enriquecimiento. Sabemos, sin embargo, que la mujer real del barroco estaba en una situación mucho más difícil que la del varón, puesto que el salirse de los roles impuestos por la ideología dominante, patriarcal, conservadora, represiva y misógina, implicaba convertirse de inmediato y por consenso en una ramera. Con meridiana claridad lo ha explicado Julio Rodriguez-Luis:

"Una mujer pobre tenía, por supuesto, muchas menos oportunidades de éxito en una carrera picaresca que un hombre debido a factores tales como su menor educación, su absoluta dependencia de los hombres y la desconfianza de la ley hacia ella. Hablando desde un punto de vista 
realista, la única puerta abierta a una mujer cuyo origen social y ambición eran similares a los del pícaro era la prostitución, y ésta sola no podía elevarla a la posición disfrutada por las pícaras literarias en la cúspide de sus carreras. Ésta es la razón por la cual Justina no es realmente una pícara sino la encarnación del ingenio de López de Úbeda. Las pícaras, en oposición a las meras prostitutas, eran de hecho imposibles en una sociedad que imponia tantas pesadas constricciones a la movilidad social de una mujer normal."

Según el citado crítico, la represión social a que estaba sometida una mujer de bajo origen provoca, inevitablemente, la inverosimilitud del relato y la falta de profundidad de los caracteres:

"Como consecuencia, las novelas picarescas que se refieren a las picaras carecen de la característica profundidad de las novelas que tratan de sus compañeros masculinos. Esta profundidad resulta de la tensión entre ambición y medios, una tensión que, si bien es creativa o artisticamente válida, debe basarse en una esperanza realistica. Sin embargo, lo que de hecho ocurre en las novelas de pícara es una suspensión de la verosimilitud interna del obra, algo que sólo puede ser fatal para una novela basada en la imitación de la realidad. Es igualmente cierto, por supuesto, de algunas novelas menores relativas a picaros, pero en ellas no sentimos la marcada inverosimilitud que tan intensamente debilita a las picaras en cuanto carácter literario creible." (RodriguezLuis (1979), págs. 30-40. La traducción es mia).

No creo, sin embargo, que la inverosimilitud de la picaresca femenina venga motivada únicamente por la imposibilidad de los autores para inspirarse en un modelo real. De hecho, tan inverosímil como que una pícara se casase con un capitán es que un pícaro como Pablos, hijo de un ladrón y de una hechicera, pensase seriamente que podía convertirse en caballero. Además, si los pícaros se ganaban la vida sirviendo a un amo, ¿por qué ningún autor se propuso recrear la vida de una pícara-fregona que con engaños más o menos risueños intentara enriquecerse? ¿Por qué no hay arcones con panecillos prohibidos ni tarros de miel trucados en la novela picaresca femenina? ¿por qué las tretas han perdido toda su ingenuidad para trocarse en malignas artimañas de burla y venganza? ¿por qué ese afán de las pícaras por alcanzar el triunfo a toda costa, cuando el Lazarillo se conforma con su oficio de pregonero de vinos, Pablos afronta su mala suerte y se embarca hacia las Indias y Simplicius renuncia a las riquezas y vanidades mundanas para entregarse a la vida eremítica? Y en fin, ¿por qué tenemos que esperar a Moll Flanders para encontrar, no sólo verosimilitud -como señala Julio Rodríguez-Luis-, sino también una mirada comprensiva, humana y respetuosa por parte del autor?

Creo que estas preguntas no pueden responderse apelando únicamente a la distancia insalvable entre ambición y medios.

\section{Conclusiones: exageración y distorsión como estrategias de autodefensa.}

$\mathrm{El}$ éxito de la pícara, impensable en el siglo XVII, refleja el temor de la colectividad masculina al ascenso e independencia de la mujer. La pícara no es sólo el esperpento moldeado por la mirada misógina del autor; es también la encarnación literaria de la mujer fatal del Barroco, el fruto malicioso de una obsesión oculta, el símbolo de una amenaza intuida. El tipo de mujer que ella representa (independiente, segura, rebelde, sensual y dominadora) traslada al mundo novelesco la pesadilla intima del hombre barroco, atormentado por las crecientes muestras de inconformismo femenino.

Desde fines del siglo XVI, la mujer habia comenzado a rebelarse contra las normas impuestas por la ideología dominante: encerramiento, castidad, silencio, obediencia y sumisión: programa de 
vida más conventual que conyugal. La mujer no quiere envejecer entre las paredes de una casa. Le gusta pasear, bailar, cantar, divertirse, participar en las conversaciones, lucir hermosos vestidos y resaltar su belleza con afeites. Pretensiones tan desorbitadas ponen sobre aviso a la población masculina y desencadenan una corriente de pensamiento antifeminista que se expresa con acritud en literatura y que tiene su versión moralizante en la proliferación de libros de doctrina dirigidos a las mujeres.

La presión alienadora y tiránica de la sociedad barroca no es suficiente, sin embargo, para neutralizar la sensualidad de la mirada y el cuerpo femeninos; de ahí que el erotismo, tan presente en la picaresca femenina, sea contemplado ahora más que nunca como un arma peligrosa capaz de anular la voluntad del varón.

Es cierto que el sexo es un tema constante de la literatura e iconografía medievales. Recordemos, por ejemplo, el pasaje de las horas canónicas del Libro de buen amor de Juan Ruiz, manual en clave sagrada del más obsceno amor sexual. Pero si en la Edad Media estos desvios no atentaban contra la ordenación social (cada uno conocía su papel y se mantenía en su puesto), en el siglo XVII el sistema se está derrumbando y los hombres temen que la mujer aproveche la confusión y los dones naturales de su sexo para ascender en la escala social y desplazarlos de sus poderes de mando. Son interesantes en este sentido las siguientes palabras de Maravall:

"En las circunstancias de la época, en el miedo a la subversión del orden que promueve toda la crisis social del Barroco, se hace frecuente sostener que lo que la mujer pretende va mucho más allá: persigue utilizar sus atractivos, capaces de despertar pasiones irreprimibles en el hombre, al objeto de invertir el orden social y natural que atribuye a aquél el poder de dominación en la sociedad y particularmente en las relaciones de hombres y mujeres, contra lo cual se maquina hasta lograr trasferir a éstas el gobierno. Este es el gravisimo nudo de la cuestión, lo que enciende esa irritación de la misoginia barroca y hace enterrar a la mujer en un círculo de desconfianza, bien que en la época se halle en condiciones de saltárselo por lo menos ocasionalmente." (pág. 693)

Me parece esclarecedor y necesario poner en relación este temor de la población masculina a la inversión de los roles tradicionales con el personaje literario de la pícara, mujer independiente y liberada, capaz de triunfar y de engañar al hombre. La inverosimilitud no es una mera opción artística motivada por las escasas posibilidades creativas que ofrecía un relato ceñido a la realidad. La inverosimilitud es una consciente opción ideológica en una novela con proyección de futuro: una novela que se dirige a un lector cómplice y solidario para avisarle de lo que puede llegar a suceder si los hombres no controlan a tiempo a las indómitas mujeres. El resultado sería desatroso: un mundo donde el varón sería casi un muñeco y donde se multiplicarian las mujeres con el impetu de Coraje y de Justina; un mundo donde se harian realidad las seis cláusulas del contrato matrimonial de Springfield (cap. XV) y el "así se hará" amenazante de Coraje:

“...Springfield... habia de seguirme. ¿Qué cosa podría evitarlo? ¿Cuán maravillosa criatura marina habría tenido que ser?... Y así se hará mientras que otras mujeres de gran resolución como yo puedan hacer caer (no quiero decir empujar) en trampas semejantes a los calaveras de sus maridos (si tuviera que llamarlos de otra manera diria más bien "pios maridos"), puesto que hasta ahora no han suscrito en su matrimonio acuerdo alguno como el mío..." (pág. 162)

Evidentemente, estas pícaras inventadas por los miedos ocultos de los varones nunca podrian alimentar las pretensiones de liberación de las doncellas barrocas. La razón es sencilla: eran pocas las mujeres que sabían leer y escribir, y éstas recibian una educación fuertemente ideologizada: libros 
de moralidad y poesía cortés, novela rosa del XVII que narcotizaba las almas femeninas con engañosos ensueños de amor y falsas promesas varoniles de eterna servidumbre: ficción de fícciones.

El público de la novela picaresca femenina es exclusivamente masculino. Grimmelshausen se dirige expresamente a "recatados donceles, honestos viudos y hombres casados", que son -cómo dudarlo- víctimas fáciles de las nefastas mujeres. Resulta evidente, por tanto, que las palabras antes citadas de Coraje no han sido concebidas para promover la emancipación femenina (nada más conservador y reaccionario que estos relatos). Con el amenazante e incisivo parlamento que pone en boca de la picara, el autor avisa a los varones del peligro implícito en adoptar actitudes benignas y comprensivas con las mujeres; de la necesidad, por tanto, de no ser demasiado "pios" con ellas.

La novela picaresca femenina se dirige a la voluntad, no a la razón, y pretende producir el rechazo, no la catarsis. Esto lo consigue mediante la hipérbole y la parodia. Coraje es una caricatura; Justina, una marioneta que ni siquiera tiene voz propia. Resultaba imposible que el lector se identificara con la protagonista porque la risa es distanciadora. Una mujer vestida de hombre y luchando en el ejército como cualquier soldado produciria la hilaridad y después, el desprecio y la censura. También López de Ùbeda supo tejer con maestria los hilos para que la hidalguía de Justina -su sueño realizado- revirtiese en la propia ridiculización del personaje.

Es evidente, de hecho, que picaro y picara son tratados - contemplados, diseñados, juzgadosde forma radicalmente distinta por parte de los autores. ¿Por qué fracasan los intentos matrimoniales de Guzmán y Pablos cuando se proponen conquistar a una mujer rica y noble para salir de la miseria? $\mathrm{Al}$ fin y al cabo, pícaros y pícaras recurren al único medio posible: fingir lo que no se es. La pícara finge virtud como el pícaro finge nobleza y dinero. La razón es clara: un matrimonio ventajoso para el pícaro no hubiera sido nada moralizante; al contrario, además de atentar contra el estatuto del realismo, hubiera impedido el proceso de reflexión interior del pícaro y su evolución hacia la conversión. En la picaresca femenina del XVII la moralización tiene una importancia muy secundaria; es más bien una excusa para introducir el mensaje antifeminista, único objetivo de estas novelas. Interesa que la picara triunfe para corroborar la astucia innata y maliciosa de la mujer y la necesidad que tiene el hombre de precaverse contra ella. Se da por sentado que la pícara, en cuanto fémina, no tiene claridad mental suficiente para reflexionar sobre su trayectoria vital y proponerse un cambio de rumbo. La conversión no entraba dentro de las pautas de comportamiento que la ideología antifeminista atribuía a la mujer.

La consideración de la perspectiva ideológica que determina aprioristicamente la evolución de la peripecia y la caracterización de los personajes sirve también para comprender la peculiaridad de la picaresca frente a otras novelas coetáneas. Piénsese, por ejemplo, en el contraste existente entre la pícara Justina y la Maritormes cervantina: mesonera y ramera como ella, pero sin fobias ridiculas ni deseos de venganza; mujer inculta y primaria que, a pesar de la ruindad de su entorno y de su oficio, es capaz de entusiasmarse con las escenas de amor cortés de los libros de caballerias. Lo que cambia es la mirada del autor: altruista y cálida en Cervantes, burlona y sarcástica en López de Úbeđa.

Comparada con La pícara Justina y con La picara Coraje, Moll Flanders es, sin embargo, una novela diferente, como también lo es el contexto social, económico, cultural e ideológico al que pertenece. En principio, el público es más amplio. La alfabetización en la Inglaterra dieciochesca es mucho mayor que en la España del siglo anterior y sin duda, había llegado a las mujeres. La misoginia persiste en la novela, pero muy suavizada. Descubrimos el tópico de la lascivia y debili- 
dad femeninas en las constantes inculpaciones que Defoe pone en boca de la propia protagonista, que se confiesa culpable de la consumación del acto amoroso:

"Y entonces, como me tenía entre sus brazos, me besó tres o cuatro veces. Yo forcejeé para desasirme, pero lo hice débilmente, y él me abrazaba y siguió besándome hasta quedar casi sin aliento y entonces se sentó y me dijo: Querida Betty, estoy enamorado de vos." (pág. 26)

"...la verdad es que empezó a mostrarse ardoroso conmigo. Tal vez me encontró un poco demasiado fácil, pues bien sabe Dios que no le opuse ninguna resistencia mientras sólo me tenia entre sus brazos y me besaba; la verdad es que estaba demasiado complacida con aquello para poder resistirle mucho." (pág. 27)

“...yo soy un buen ejemplo para todas las jóvenes en las que la vanidad prevalece sobre la virtud. Tanto el uno como el otro obrábamos del modo más estúpido que puede imaginarse. De haber obrado yo como debía, y de resistirle como exigen la virtud y la honra, aquel caballero, o bien hubiese desistido de sus intentos, viendo que no había motivo para esperar el éxito de sus propósitos, o bien me hubiera pedido en matrimonio de un modo honrado y formal." (pág. 30)

En cualquier caso, Defoe es comprensivo y respetuoso con la protagonista de su novela. Moll es la primera pícara que tiene voz propia; la primera pícara que habla y siente como mujer. De ahi que el tono de muchos pasajes, de páginas enteras, sea sincero y conmovedor, sobre todo en aquellos momentos en los que Moll analiza con dolor la marginación social de la mujer en su época. $\mathrm{Ni}$ López de Ubeda ni Grimmelshausen hubiesen permitido a sus picaras hablar con esta franqueza:

"Y ahora a mí sólo me resta recordar a las damas lo mucho que ellas mismas se rebajan respecto al nivel medio de lo que es una esposa, que, y creo que al decir esto no soy parcial, es ya bastante bajo; decía que ellas mismas se rebajan respecto a este nivel medio, y ellas mismas preparan el camino de su propia humillación, resignándose de antemano a ser victimas de los hombres, de lo cual confieso que no creo que exista ninguna necesidad.” (pág. 83)

“... que los tiempos están tan corrompidos, y el sexo fuerte tan viciado, que, para decirlo en pocas palabras, el número de hombres con los que una mujer honesta deberia tener trato, la verdad es que es escasísimo, y que es muy raro encontrar a un hombre que sea digno de que una mujer confie en él. (...)

$Y$ en cuanto a las mujeres que..., impacientes por llegar a un estado más perfecto, deciden, como ellas mismas dicen, aceptar al primer llegado, que van al matrimonio igual que un caballo se precipita en medio del fragor de la batalla, a éstas sólo puedo decirles una cosa: que son mujeres que necesitan que se ruegue por ellas como se hace por las demás personas perturbadas (...).

Yo desearía que las de mi sexo se condujeran con un poco más de sensatez en estas cosas ya que a mi entender éste es un problema que en nuestros tiempos nos afecta más que ningún otro; no es más que falta de valor, el miedo a no casarse ni mal ni bien, y el miedo a convertirse en uno de estos tristísimos personajes que se llaman solteronas, (...). Quien se une a un mal marido siempre se casa demasiado pronto, y nunca se casa demasiado tarde quien se une a un buen esposo." (págs. 84-85)

Recordemos finalmente la triste reflexión de Moll ante la ruin estrategia urdida por el hermano mayor de los Colchester para eludir sus promesas de matrimonio:

"Así es ciertamente como el egoismo atropella todo género de afectos, y así es como los hombres tienden a obrar naturalmente, olvidando el honor y la justicia, la humanidad e incluso su condición de cristianos, para defender su tranquilidad." (pág. 65)

Moll no es un esperpento ni una caricatura: es una mujer auténtica, con miedos, dudas, problemas y sueños. Moll siente como nunca lo hicieron las otras. Sus engaños no son burlas crueles, hirientes ni arbitrarias como las que emprendian Justina y Coraje para mofarse de los demás hombres. Ellas jamás sintieron remordimientos; Moll, sí: 
"Yo me volvi de espaldas, porque también en mis ojos habia lágrimas, y le pedí licencia para retirarme un poco a mi alcoba. Si alguna vez he sentido algo de verdadero remordimiento por mi vida viciosa y abominable de mis últimos veinticuatro años, fue entonces. ¡Qué felices son los hombres -me dije a mí misma- al no poder leer en los corazones de los demás! ¿Qué felicidad la mía si en un principio me hubiera casado con un hombre tan honrado y afectuoso!" (pág. 202)

Tampoco el sexo recibe el mismo tratamiento. En las novelas del XVII, erotismo y prostitución son sinónimos. Con Moll Flanders se dignifica el sexo vinculándolo por vez primera al amor:

"El perderle como amante no me afligía tanto como perderle a él mismo, pues la verdad es que le amaba hasta la locura: y el perder todas mis ilusiones sobre las que había edificado mis esperanzas de que un dia llegaria a ser mi esposo." (pág. 47)

También se refiere al ingrato Colchester cuando confiesa: “...la verdad es que lo amaba hasta un extremo difícil de imaginar" (pág. 63). El caballero de Lancaster fue su segundo y último gran amor. Cuando él se ve obligado a abandonar Londres, Moll cae en un estado de histerismo y desesperación:

"Oh, Jemmy! -decia-, jvuelve, vuelve! Te daré todo lo que tengo; mendigaré, pasaré hambre a tu lado. Y así iba de un lado a otro de la estancia, como loca, y luego me sentaba, y volvía a andar por la habitación, llamándole y diciéndole que volviera, y luego echándome a llorar de nuevo; y asi pasé toda la tarde... cuando, ante mi indecible sorpresa él regresó... empecé a debatir conmigo misma si debía alegrarme o entristecerme; pero mi amor se sobrepuso a todo lo demás y no me fue posible ocultar mi alegria, que era demasiado grande para expresarse con risas, y rompi a llorar." (pág. 172)

En la Inglaterra del siglo XVIII el matrimonio seguía siendo el único estado aceptable para una mujer honesta y el único medio que tenía una doncella pobre para escapar de la miseria. Pero ¿qué habría ocurrido si el hermano menor de los Colchester no hubiese estado ebrio en la noche de bodas? Defoe, consciente de la injusta marginación femenina, deja que Moll exprese su queja ante la inexorabilidad de un destino dirigido por los hombres y confabulado contra ella:

"...cuando una mujer queda así desamparada y sin nadie que la aconseje, es como una bolsa de monedas o una joya perdida en medio de un camino, que será para el primero que pase por alli; si la suerte hace que quien la encuentre sea un hombre virtuoso y de rectos principios, hará avisar y quizá su dueño pueda recuperarla; ;pero cuántas veces ocurrirá que la encontrará quien no tendrá el menor escrúpulo en quedársela, en vez de ir a parar en buenas manos!

Evidentemente, éste era mi caso... . Quería conseguir una situación estable en la vida, y de haber tropezado con un buen esposo, con un hombre digno, hubiese sido para él una esposa tan fiel y abnegada como puede serlo un modelo de virtud, pero en mi situación el vicio llamaba siempre a la puerta de la necesidad... ." (pág. 144)

En cualquier caso, Defoe permite a Moll que rehaga su vida en Virginia mientras que Grimmelshausen abandona a Coraje en una tribu de gitanos y López de Úbeda se ríe de su propio personaje obligándole a que se resigne con una pobrísima hidalguía.

Indudablemente, la evolución de la sociedad europea favorecía la aparición de una picaresca más verosimil y menos anti-feminista. En una sociedad como la protestante, que valoraba el esfuerzo personal y hacía de la competitividad una fuente legitima de riqueza, la mujer, aun siendo de bajo origen, tenía muchas más posibilidades reales de medro. No es menos cierto, sin embargo, que la actitud abierta y comprensiva de Defoe está detrás de la humanidad y autenticidad de Moll y que nada le hubiera impedido dar un final de castigo a su novela: Moll encarcelada o definitivamente condenada a la prostitución. Pero no lo deseaba. No es la suya una mirada distorsionadora 
y censoria. Defoe no es un manipulador burlón como Úbeda ni un inquisidor como Grimmelshausen, que convierte a Simplicius en un santo y a Coraje, en la más lasciva de las pícaras.

En Moll Flanders la mirada ha cambiado porque también la sociedad dieciochesca ha suavizado la misoginia heredada del Barroco. Estamos comenzando el Siglo de las Luces. Inglaterra acaba de estrenar el primer sistema parlamentario de Europa y Francia no tardará en proponer la división de poderes. Pronto se divulgarán las ideas de igualdad de Rousseau y el Tratado de la tolerancia de Voltaire. La Ilustración reivindica el poder liberador del conocimiento, descubre la bondad natural del hombre tras siglos y siglos de pecado original, apuesta por una sociedad fraternal e igualitaria y apoya una revolución contra el Antiguo Régimen. Cultura, ambición, afán de renovación, espíritu critico y altruismo son las características del nuevo espíritu.

Este talante de comprensión y concordia tuvo que afectar también a la relación hombre-mujer. Al fin y al cabo, la misoginia medieval y barroca se habia convertido en una especie de dogmatismo que el hombre ilustrado no estaba dispuesto a aceptar sin someterlo a la criba de la razón analítica. Como resultado de esta nueva actitud, se produce una reinterpretación de la mujer, que deja de ser enemiga para convertirse en compañera. El futuro proyectado es un futuro de pareja. No hay Pablo sin Virginia.

EN RESUMEN, la evolución económica de la sociedad y, sobre todo, la perspectiva ideológica de los autores -sujetos sociales e históricos-imprimen diferencias importantes entre picaresca masculina y femenina y entre picaresca femenina barroca y dieciochesca. Frente al realismo moralizante de las novelas de pícaro, la picaresca femenina se caracteriza por su inverosimilitud y su marcado antifeminismo. Novelar es manipular. El personaje -plano, monocorde y carente de autenticidad- se convierte en marioneta del autor.

El estudio del tema del medio social pone de manifiesto la importancia del miedo al ascenso femenino en la intensificación de la misoginia durante los siglos XVI y XVII. El triunfo de las pícaras traslada a la literatura la preocupación masculina ante la posibilidad de un cambio en los roles tradicionales. Además de divertir y entretener, la novela picaresca femenina pretende avisar, prevenir y aconsejar a los lectores.

En el siglo XVIII, el progreso económico de la sociedad redunda en beneficio de la verosimilitud del relato al tiempo que la evolución ideológica favorece una actitud más comprensiva y se desliga de los extremismos misóginos del siglo precedente. Disminuye la desconfianza del hombre hacia la mujer y el prejuicio de la bondad masculina frente a la congénita maldad femenina no es ya tan determinante. Como consecuencia, el relato gana en humanidad y la pícara, en complejidad psicológica. El autor, mucho más tolerante y comprensivo, se esforzará por construir un personaje con voz propia.

\section{Notas}

1 A partir de ahora, las citas e indicaciones de páginas remiten siempre a las siguientes ediciones:

- Alemán, Mateo, Guzmán de Alfarache, edición, introducción y notas de Francisco Rico, Planeta, Barcelona, 1983.

- LÓPEZ DE ÚBEDA, Francisco, La picara Justina, ed. Ramón Sopena, S. A., Barcelona, 1981.

- Grimmelshausen, H. J. Ch., La picara Coraje, ed. José Manuel González, Cátedra, Madrid, 1992.

- DefoE, Daniel, Moll Flanders, ed. Carlos Pujol, Cátedra II, Madrid, 1981.

2 De hecho, tal y como señala Dominguez Ortiz, es caracteristico del espiritu español, frente al resto de Europa, una cierta desmesura en la defensa de la propia dignidad personal: "desmesura que llevó a los extranjeros a considerar el orgullo como un rasgo caracteristico de nuestro pueblo, comentándolo con indignación o con sorna: "los españoles tienen 
en todas sus acciones un no sé qué de altivo y de magnífico, -escribía Fulvio Testi-. Hasta para celebrar la misa usan hostias dobles de grandes que en Italia." Los españoles tambièn estaban de acuerdo en que éste era un rasgo del carácter nacional, sobre todo (y esto era una diferencia con el resto de Europa) en cuanto era extensivo a todas las capas sociales, incluso las más humildes."

A esta extensión del orgullo personal en el pueblo llano (incluso picaros y celestinas tenian honra) contribuyó la pervivencia en la Edad Moderna de los estatutos de limpieza de sangre. Comenta el citado autor:

"De aqui resultaba una situación muy compleja y confusa que sorprendia a los observadores extranjeros; la sociedad hispana parecia muy jerarquizada y a la vez muy igualitaria puesto que al ser el honor patrimonio común las demás distinciones resultaban accidentales. "Entre los españoles no hay plebe; todos nacen con ánimos grandes", escribia un autor de fines del siglo XVII. Y Saavedra Fajardo, con su conocimiento directo de otras naciones, señalaba también esta caracteristica de nuestro pueblo: "El espiritu altivo y glorioso (aun en la gente plebeya) no se quieta con el estado que le señaló la Naturaleza y aspira a los grados de nobleza, desestimando aquellas ocupaciones que son opuestas a ella; desorden que tambièn proviene de no estar como en Alemania, más distintos y señalados los confines de la nobleza." En realidad, esos limites si estaban bien claros "en teoria"; era noble quien nacía noble; ni siquiera la voluntad real podia otorgar más que una nobleza de segundo orden, una "nobleza de privilegio". Lo que ocurria es que habia un gran dinamismo social, unas circunstancias que facilitaban la capilaridad social y unos recursos excepcionales que no se daban más que en España: los estatutos de limpieza, producto de la mezcla de razas y religiones que tuvo lugar en la Eđad Media y que dejó hondas huellas en la Moderna; con frecuencia los villanos se desquitaban del orgullo y los privilegios de los hidalgos recordándoles que eran limpios de sangre como ellos, y a veces más que ellos. Era éste un fenó meno tipicamente español; en todas partes se hacian pruebas de nobleza; también era general la aversión a los oficios "viles y mecánicos" y al pequeño comercio, pero sólo en España se hacían pruebas de limpieza de sangre que afectaban a todas las clases sociales, e incluso en mayor grado a las elevadas". (Dominguez Ortiz, "La sociedad española en el siglo XVII", en Menéndez Pidal (1990), Tomo XVIII, pág. 397-398).

3 Las pragmáticas son igualmente una buena prueba del poder que tenia el dinero para ascender en la escala social:

" Si las pragmáticas sobre porte de vestidos servian para separar la clase baja de la media, las referentes a los coches discriminaban la media de la alta ... La pragmática de 1684 , reiterada en 1723 , vedaba su uso a los alguaciles, escribanos, notarios, procuradores, agentes de negocios, mercaderes, plateros, receptores, obligados, maestros y oficiales de gremios.

Disposiciones de este tenor respondian a la irritación que en los defensores del orden tradicional producia la subversión introducida en el mismo por la irrupción de las categorias crematisticas; era una de tantas manifestaciones defensivas de la hidalguía frente a la burguesía; pero éste era un pleito perdido, porque la asimilación de los ricos, de cualquier procedencia que fueran, a los nobles era una tendencia irresistible. Lo dice claramente un defensor decidido de la tradición, el inquisidor Escobar de Corro: "Por eso vemos que los ricos gozan de los mismos pribilegios que los nobles, no se les ahorca, no se les condena a penas infamantes, no se les somete a tormento..." (Domínguez Ortiz, "La sociedad española en el siglo XVII", en Menéndez Pidal (1990), Tomo XVIII, Parte tercera, págs. 401-402).

4 Para justificar este desbocado deseo de los plebeyos por convertirse en hidalgos basta repasar los numerosos privilegios de que gozaba el estado noble: inmunidad de tributos y de toda prestación personal o real (moneda forera, servicio ordinario, etc.) No podian ser atormentados. No sufrian penas afrentosas como la de azotes y galeras. No podian ser encarcelados por deudas. Debian tener prisión aparte, separada de la de los plebeyos. No se les podía embargar las armas, vestidos, caballos, lecho y casa. Las injurias que recibian estaban más penadas. En caso de pena de muerte, no eran ahorcados sino decapitados. En cuanto a dotes y contratos, también tenian algunas preferencias reconocidas por la ley; de ahí que alcanzasen el monopolio de los cargos públicos más fructuosos. (Tomado de Dominguez Ortiz, (1964) págs. 188-189).

5 Maravall, Jose Antonio, La literatura picaresca desde la historia social, ed. Taurus, Madrid, 1986, cap. VIII, pág. 366. Como veremos, la caracteristica apuntada por Maravall (novela picaresca = novela de la frustración del medro) es una de esas características no aplicables a las novelas protagonizadas por mujeres.

6 "La mujer que tiene honra y vergüenza no ha de hablar ni pensar en casarse, si no es cuando, y con quien sus padres fuere bien visto." Es la opinión del teólogo jesuita Francisco Escrivá (y de todos los moralistas de la época) en Discursos de los estados, de las obligaciones particulares del estado, y oficio, según las cuales ha de ser cada uno particularmente juzgado, Valencia, 1613, pág. 110. Citado por Mariló Vigil (1986).

7 Moll corrobora así las palabras de la hija de los Colchester, que, refiriendose a ella, habia dicho:

"A Betty (Moll) sólo le falta una cosa, pero para el caso como si le faltara todo, porque en estos tiempos a nuestro sexo no se le concede valor; y si una joven posee belleza y es de buena familia, tiene buena crianza, ingenio, buen juicio, buenas maneras, modestia, y todo ello en grado extremo, si no tiene dinero no es nadie, es como si le faltara todo, porque hoy en dia lo único que se aprecia en una mujer es el dinero: son los hombres los que tienen todas las bazas en la mano." (pág. 24)

9 Ambos refranes son recogidos por Correas en su Vocabulario y citados por Antonio Rey Hazas (1983), de donde tomo la referencia. 
10 Con esta cláusula, Coraje revela su adhesion a una práctica, la del matrimonio clandestino, muy extendida, al parecer, por toda la Europa occidental, especialmente en las zonas rurales. España no fue una excepción, como pone de manifiesto Antonio Dominguez Ruiz en "La mujer. La sexualidad. La familia”:

"Es en este ámbito popularista donde intentó mantenerse, a pesar de la prohibición del Concilio de Trento, el matrimonio clandestino, apelación peyorativa que se atribuyó al matrimonio sin asistencia del párroco, de muy antigua tradición; en él se apreciaba la virginidad de la mujer, pero sin llegar a la tragedia. La facilidad de las gallegas era producto de una cultura agraria distinta de la muy urbana, teologizada y caballeresca Castilla, escenario obligado de los dramas de Calderón. Pero el hecho de la prohibición de que los novios, los desposados, cohabiten antes de recibir el sacramento se repita en las constituciones sinodales de todas las partes de España indica que esta muy antigua costumbre seguia teniendo vigencia entre las clases populares de todas las regiones.

Dicha costumbre mereceria un detenido estudio; no se puede explicar meramente por liviandad; algo influiria el temor a la ligadura (impotentia coeundi), maleficio que impedia a los recién casados consumar el matrimonio. Sin embargo, hay otra explicación más general: la convicción de que los desposorios, las palabras de presente y aun la simple promesa verbal o escrita, constituian ya, si no un matrimonio completo, si un matrimonio incoado, un compromiso formal que autorizaba la vida en común; las bendiciones serian entonces la perfección, la ratificación de una situación legal ya existente. Citaremos sólo dos ejemplos, uno del norte y otro del sur de España para mostrar su universalidad: las constituciones sinodales đe Pamplona del año 1591 dicen (pág. 129): "Hay muchos que sin haber recibido las bendiciones nupciales cohabitan juntos como marido y mujer, contra lo dispuesto por el Concilio de Trento... Por tanto ordenamos que ningunas personas después de ser desposadas no cohabiten sin ser veladas y sin haber recibido las bendiciones de la Iglesia so pena de tres ducados." Casi un siglo después, en 1671, las constituciones de Málaga (folio 108) declaran corruptela aún no totalmente extirpada, que los concertados de casar (que llaman otorgados) entran en casa de las novias y comunican carnalmente con ellas."

La decadencia de esta costumbre es paralela a la de los propios desposorios, fenómeno europeo. Chaunu se ha referido al paulatino eclipse de esta institución, tal y como puede seguirse a través de los registros parroquiales. Al llegar el siglo XVIII, casi ningún párroco anota ya los desposorios como ceremonia distinta del matrimonio propiamente dicho." (Domínguez Ortiz, La mujer, la sexualidad, la familia”, en Menéndez Pidal (1990), Parte tercera, pág. 412).

11 Con razón podemos decir, por tanto, utilizando las palabras que Cervantes pone en boca de Berganza en El coloquio de los perros, que Justina y Coraje eran "dos mujercillas, no de poco más o menos, sino de menos en todo; verdad que tenian algo de buenas caras, pero mucho de desenfado y de taimería putesca. (...) Vestianse de suerte que por la pinta descubrian la figura, y a tiro de arcabuz mostraban ser damas de la vida libre." Cervantes (1981), pág. 324.

\section{Bibliografia}

ALEMÁN, Mateo, Guzmán de Alfarache, edición, introducción y notas de Francisco Rico, ed. Planeta, Barcelona, 1983.

BATAILLON, Marcel, Picaros y picaresca: La picara Justina, Taurus, Madrid, 1969.

BLANCO AGUINAGA, Carlos, "Picaresca española, picaresca inglesa: sobre las

determinaciones del género", Edad de Oro, II (1983), págs. 49-65.

CASTILLEJO, Cristóbal de, Diálogo de mujeres, Castalia, Madrid, 1986. Edición de Rogelio Reyes Cano.

CERVANTES, Miguel de, Novelas ejemplares, Cátedra II, Madrid, 1981.

DEFOE, Daniel, Moll Flanders, ed. Carlos Pujol, Planeta, Barcelona, 1981.

GRIMMELSHAUSEN, H. J. Ch., La picara Coraje, ed. José Manuel González, Cátedra, Madrid, 1992.

GUILLEN, Claudio, "Toward a definition of the Picaresque", Literature as a system: Essays toward the Theory of Literary History, Princeton University Press, Princeton, 1971.

HANRAHAN, Thomas, La mujer en la novela picaresca española, ed. José Porrúa Turanzas, Madrid, 1967.

LEITES, Edmund, La invención de la mujer casta, Siglo XXI, Madrid, 1990.

LÓPEZ DE UBEDA, Francisco, La picara Justina, ed. Ramón Sopena, S. A., Barcelona, 1981 (publicado como anónimo).

MARAVALL, José Antonio, La cultura del Barroco, Ariel, Barcelona, 1975.

MARAVALL, José Antonio, La literatura picaresca desde la historia social, Taurus, Madrid, 1986.

MENÉNDEZ PIDAL, Ramón, Hisioria de España. La crisis del siglo XVII. La población, la economia, la sociedad, tomo XVIII, Espasa-Calpe, S.A., Madrid, 1990, 2a edición.

MOLHO, Maurice, Introdución al pensamiento picaresco, Anaya, Salamanca, 1972.

PARKER, Alexander A., Los picaros en la literatura. La novela picaresca en España y Europa, 1599-1753, Gredos, Madrid, 1971. QUEVEDO, Francisco de, Historia de la vida del buscón llamado don Pablos, Cátedra, Madrid, 1983.

REY HAZAS, Antonio, "La compleja faz de una pícara: hacia una interpretación de La picara Justina", Revista de Literatura no 90 (julio-diciembre, 1983). 
RICO, Francisco, La novela picaresca y el punto de vista, Seix-Barral, Barcelona, 1982.RODRÍGUEZ-LUIS, Julio, "Picaras: the Modal Approach to the Picaresque", Comparative Literature (Winter, 1979).

VIGIL, Maria Dolores, La vida de las mujeres en los siglos XVI-XVII, Siglo XXI, Madrid, 1989.

WICKS, Ulrich, "The Nature of Picaresque Narrative: A Modal Approach", PMLA, 89, n 2 (1974), págs. 240-249.

WICKS, Ulrich, Picaresque Narrative. Picaresque Fictions. A Theory and Research Guide, New York: Greenwood Press, 1989.

\section{ŽENOMRZNIŠTVO ALI STRAH V ŽENSKEM PIKARESKNEM ROMANU}

Ženski pikareskni roman je živel vedno v senci pikaresknega romana, v katerem so glavni junaki moški (od Lazarčka s Tormesa do Grimmelshausenovega Simplicius Simplicissimus). Glavne značilnosti potepuškega romana so jasno določene $\mathrm{z}$ romanom Guzmán de Alfarache avtorja Matea Alemána. Vendar številne značilnosti moškega pikaresknega romana niso uporabne, vsaj v absolutnem pomenu, $v$ ženskem pikaresknem romanu.

Junakinje-klateži imajo določene posebnosti tako zaradi samega spola kot zaradi oddaljenosti med avtorjem in avtobiografskim pripovedovalcem. Glavne junakinje se morajo tako prilagoditi strogi patriarhalni družbeni ureditvi; prav tako pa se razkorak med avtorjem in pripovedovalko spremeni v ideološko obarvano manipulacijo besedila.

Avtorica v članku obravnava naslednja besedila: La Picara Justina (Francisco López de Ubeda, 1605), La Picara Coraje (H. J. Ch. von Grimmelshausen, 1670) in Moll Flanders (Daniel Defoe, 1722). V njih si junakinje želijo boljšega družbenega položaja, ki ga v romanih tudi dosežejo. Vendar gre le za fikcijo in ne za odsev stvarnosti, v kateri v tistem obdobju prevladuje izrazito ženomrzništvo. 